\title{
An imaging review of extramedullary myeloma
}

\author{
M Kay ${ }^{*}$, A King, B Shepherd, E Rutherford, J Smart, K Tung \\ From International Cancer Imaging Society Meeting and 15th Annual Teaching Course (ICIS 2015) \\ London, UK. 5-7 October 2015
}

\begin{abstract}
Learning objectives
Numerous studies have demonstrated increasing overall survival in patients with multiple myeloma over the last 40 years. Novel agents including thalidomide and bortezomib used in induction therapy, together with autologous stem cell transplant in consolidation, have improved patient outcomes. Whilst extramedullary myeloma can be a presenting form of the disease, it is becoming increasingly recognised that extramedullary disease is common in patients who have relapsed disease, often after multiple lines of therapy. Whether this is due to either a possible "sanctuary site" effect from treatment in extramedullary tissues, prolonged overall survival leading to an evolution in the natural history of the disease, or the improved sensitivity of imaging techniques is not clear.
\end{abstract}

\section{Content organisation}

We present a multimodality pictorial review of cases of extramedullary myeloma imaged at our tertiary oncology institution, demonstrating the common appearances on conventional imaging and the advantages of functional imaging such as PETCT in these cases.

\section{Conclusion}

Being aware of the possibility of extramedullary disease, especially in cases of disease relapse, and the common imaging appearances, is vital due to the increasing incidence of this manifestation of the disease.

Published: 2 October 2015

doi:10.1186/1470-7330-15-S1-P12

Cite this article as: Kay et al: An imaging review of extramedullary myeloma. Cancer Imaging 2015 15(Suppl 1):P12.

* Correspondence: michael.kay@uhs.nhs.uk

University Hospital Southampton, Tremona Road, Southampton, Hampshire, SO16 6YD, UK original work is properly cited. The Creative Commons Public Domain Dedication waiver (http://creativecommons.org/publicdomain/ zero/1.0// applies to the data made available in this article, unless otherwise stated. and take full advantage of:

- Convenient online submission

- Thorough peer review

- No space constraints or color figure charges

- Immediate publication on acceptance

- Inclusion in PubMed, CAS, Scopus and Google Scholar

- Research which is freely available for redistribution \\ ( Biomed Central}

